\title{
Educating the new Chinese middle-class youth: the role of quality education on ideas of class and status
}

\author{
Arianna Ponzini ${ }^{1,2}$ (1)
}

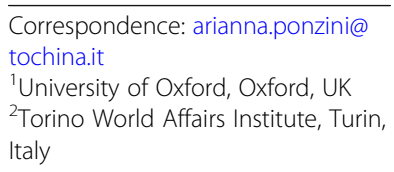

Correspondence: arianna.ponzini@ tochina.it

${ }^{1}$ University of Oxford, Oxford, UK

${ }^{2}$ Torino World Affairs Institute, Turin, Italy

\begin{abstract}
This article attempts to answer the questions: "Why is quality education so important for the new Chinese middle class and what implications does quality education have on ideas of status and social standing?" My efforts to answer these questions are guided by two key concepts: social distinction and capital convertibility, which have been presented and analyzed in the work of Bourdieu. The present article advances a new framework for analyzing the different effects of schooling and youth education on ideas of class and social status for the new Chinese middle class. I do this by exploring different dimensions of cultural capital and their effects on social standing and class membership. My core argument is that youth quality education, which implies the accumulation of cultural capital, and therefore of suzhi, is the strongest driving force affecting middle-class families' life strategies, as well as their ideas of status. Furthermore, cultural capital is the primary resource that can generate other forms of capital, essential for middle-class reproduction. Ultimately, due to the fact that in China the access to quality education is strongly connected to housing strategies, housing and neighborhood have been selected as the salient lens for analysis.
\end{abstract}

Keywords: Contemporary China, Chinese middle class, Children's education, Housing, Social class

\section{Introduction}

In summer 2017, an article entitled A Monthly Salary of 30,000 Yuan is Not Enough for My Child's Summer Vacation ${ }^{1}$ went viral on WeChat Moments. This article was written by a middle-class entrepreneur mother, who tells the story of her struggles in attempting to grant her child the best education opportunities. In the article, she specifically addresses the topic of overseas summer programs. However, her post generated a hot debate about education in China and about what middle-class families ${ }^{2}$ are willing to sacrifice in order to achieve their top education dreams.

The Chinese educational system is actually the largest state-run educational system in the world: in 2015, it had over 200 million full-time students (Ministry of Education 2016). Traditionally, Chinese people strongly believe in the importance of education in

\footnotetext{
${ }^{1}$ 《月薪三万, 还是撑不起孩子的一个暑假》

${ }^{2}$ For more in-depth studies on the new Chinese middle class, see for example the monographs "Class in Contemporary China" (2014) by David Goodman, or "Being Middle Class in China" (2018), by Ying Miao
} 
the development of the nation and of individuals, and this tradition was further strengthened by the introduction of the One-Child Policy, implemented in 1979 (Fong 2004). Since then, Chinese parents have started to nurture huge expectations towards their only child and have been willing to sacrifice their own economic and personal wellbeing in order to grant their children the best chances to achieve educational success (Fong 2004). In fact, educational expenses make up a large proportion of income expenditure for households: statistics show that the per capita expenditure of Chinese private households on education has tripled over the past decade, rising from 670 yuan in 2000 to 2637 yuan in 2016 (National Bureau of Statistics 2017). These data also comprise those cultural and recreational activities that are school-related expenditures, such as after-school extra curriculum activities: math and English lessons, and music or dancing classes also represent a proportion of private household educational expenditure.

Educating their youth is, therefore, paramount to middle-class Chinese parents, and providing their children with quality education is the dream of most middle-class families. Sure enough, educators, parents, and scholars have argued that in today's China the latest "luxury status symbol" of Chinese parents is not the latest bag by Vuitton or Gucci, but rather their children. However, why is quality education so important for the new Chinese middle class and what implications does education have on ideas of status and social standing? My efforts to answer these questions were guided by two key concepts: social distinction and capital convertibility, both introduced in the major work of Bourdieu (1984).

Social distinction is essential for individuals to secure middle-class status belonging and derives from the presence of strong symbolic boundaries that discern and separate the middle class from the working class (Bourdieu 1984). In other words, the Chinese middle class view education as one of the most powerful means to strengthen their social status in relation to the lower classes as well as the weaker members of the middle class. Therefore, data show that middle-class parents are willing to spend a small fortune on their children's education in order to obtain distinction and social status, or to use a Chinese term, dujin, which literally means gilding: this common and very visual expression refers to the power of education to increase the value and worth of individuals.

In the Chinese context and society, social distinction is deeply connected with another key concept for this analysis, which is suzhi. Suzhi, or "human quality" (Hanser 2006), is what gives value to human capital and, therefore, allows Chinese individuals to secure a place in the middle-class category and to secure strong social distinction. The "suzhi discourse" (Hanser 2006; Jacka 2009; Tomba 2014), which has been promoted by the Chinese government since the 1980s and which basically implies that individuals are qualitatively different, largely revolves around the acquisition of cultural capital, of which quality education is a great part of.

As a theoretical basis, Bourdieu's theory of the four species of capital provides a strong framework to support the analysis conducted in this article. We have already seen, when determining class identity, how a central element is class difference awareness: what differentiates one class from another are the economic and symbolic boundaries between different social classes (Bourdieu 1984). 
However, when analyzing class differences, income and wealth alone are not enough to determine class identity and membership. Therefore, Bourdieu identifies four different types of capital that are sources of power and socially valued as important elements of class distinction: economic capital (income and wealth), cultural capital (education, language and taste), symbolic capital (status and consumption patterns), and social capital (networks) (Bourdieu 1984).

At this point of the discussion, the Bourdieusian concept of capital convertibility comes into play: indeed, economic, social, and symbolic capital do not create suzhi, or human qualitative value, but cultural capital does (Anagnost 2004). ${ }^{3}$ Hence, the implication that suzhi can secure middle-class belonging and the reproduction of middleclass status in the long run is the reason why Chinese middle-class parents strongly encourage their children to pursue quality education and often organize their lives around quality school enrolment opportunities.

Quality education is, therefore, the fulcrum around which middle-class family lives and dynamics revolve.

The present article advances a new framework for analyzing the different effects of schooling and youth education on ideas of class and social status for the new Chinese middle class. I do this by exploring different dimensions of cultural capital and their effects on social standing and class membership. In fact, as briefly introduced above, cultural capital does not merely refer to education and schooling, but also to other dimensions which are reflected in individual status, behavior, and taste.

My core argument is that youth quality education, which implies the accumulation of cultural capital and, therefore, of suzhi, is the strongest driving force affecting middleclass families' life strategies, as well as their ideas of status. Furthermore, cultural capital is the primary resource that can generate the other three forms of capital (Bourdieu 1984), since it can be converted into economic, symbolic, and social capital. Therefore, cultural capital is key to securing suzhi and middle-class reproduction. Ultimately, due to the fact that in China the access to quality education is strongly connected to housing strategies, house and neighborhoods have been selected as the salient lens for analysis.

Many relevant studies have dealt with education in China and the importance of educating the Chinese youth (Tan 2015, 2019; Price 2017; Gu and et al. 2018). However, most studies dealing with education in China discuss the issues of academic performance and of China's score-centered system (Yan 2016; Tan 2019).

Other studies have looked at the relationship between education and housing. Feng and Ming (2010) and Zhang and Chen (2017) have analyzed the correlation between quality schools and housing prices in Shanghai, while further studies have analyzed the inequality in terms of educational opportunities between owners and tenants in Shanghai (Zhang and Chen 2016).

Ultimately, separate studies have looked at the Chinese middle class in relation to housing. Tomba (2010) has analyzed Chinese neighborhood planning as a way for the Chinese government to achieve social clustering and social engineering, thereby applying the concept of suzhi to neighborhoods and residential areas. The ideas of suzhi and

${ }^{3}$ See, for example, the difference in perception of the so-called "new rich" and of the middle-class: indeed, the former are viewed negatively due to their lack of cultural capital, as opposed to the middle class, which bases its membership largely on the possession of skills and knowledge, and not economic capital alone. 
social distinction, also in relation to the Chinese middle class, have been dealt with extensively (Anagnost 1997; Fong 2004; Kipnis 2006; Hanser 2008; Jacka 2009; Sun 2009; Zavoretti 2017).

However, few studies so far have examined the interconnection between quality education and ideas of class and status or have explored different dimensions and implications of cultural capital for the new Chinese middle class and its ideas of social standing. However, these effects and implications are of great significance, as they cast light on a complex phenomenon-that of the key role of quality education in Chinawhich up to now has only been partially explored. Sure enough, the Chinese middle class does not only pursue quality education for reasons of career and wealth, but also for deeper and more complex class-related implications which are presented in this article.

In this regard, due to resources and to my research focus, in this paper, I will not go into detailed schooling policies, or topics such as academic performance, as my research interest pertains the effects of quality education on the external realm of family and class-belonging. I will, however, refer to other relevant studies for more detailed readings on such topics.

As a result, my findings show how quality education is indeed able to affect cultural, economic, social, and symbolic capital of middle-class individuals and families, as well as highlight the significance of the phenomenon of "education fever" for the new Chinese middle class.

This study is the result of qualitative field research conducted in Shanghai from September 2015 to June 2016, where I held repeated in-depth interviews and participant observation with the members of eleven middle-class families (including extended family members). Although I do not go into the qualitative and ethnographic methodological details in this article, I wish to hereby provide an overview as for data collection and qualitative methods applied.

The main theoretical framework utilized was grounded theory (Glaser, Strauss 1967), which provides a methodology that allows the concerns of the social participants to emerge in context (Goulding 2002; Charmaz 2006) and is thus useful for research of a social nature. In order to answer my research questions, I used a variety of data collection strategies, which I adapted throughout the 10 months of fieldwork in order to obtain data which were significant, personal, and relevant for this study. Along with face-to-face formal semi-structured interviews, I used other more informal means of data collection, such as guided conversations in informal settings, e-mail exchanges, video-calls, and voice-messages. The selection of such a varied range of data collection approaches is mainly derived from the personal rapport I built up with the participant families, who expressed a desire to share personal experiences and thoughts through more informal means of communication as well. During my formal face-to-face interview meetings, I relied on semi-structured interviews, participant observation and a memo (Gobo 1999; Corbin, Strauss 2015), and I have recorded these interviews both in oral form on a recording device and in written form in a fieldwork diary.

In line with the major categories identified during the data categorization process, the article is organized around three core dimensions or thematic findings (entitlement to property-renters vs owners, status by association-quality schools and neighborhood segregation, and cultural status-middle-class reproduction goals) through which 
education and schooling are able to affect middle-class families' ideas of class and status. I have, furthermore, linked these three dimensions to the four types of capital described by Bourdieu in his analysis of class (Bourdieu 1984): economic, symbolic, social, and cultural capital. I will now look at these three dimensions in turn, also availing myself of interview extracts provided by the participants to give voice to ideas and experiences of the new middle class.

\section{Quality education and economic capital: renters vs homeowners}

The first dimension I explore pertains to the effects of quality education on middleclass families' economic capital, specifically in regards to their homeownership goals and aspirations.

In one of our conversations, Mrs. Meng explained:

"In contemporary Chinese society, owning a home is a key way for families to secure the best education for one's child. Although it is not easy, my husband and I are determined to do anything we can to purchase a house before our child comes of school age. Renters have many disadvantages when it comes to accessing public schools, and we want to give our child the best education opportunities."

Regulations within the Chinese educational system are, in fact, quite strict: not only is a neighborhood school policy enforced ${ }^{4}$ (Feng and Lu 2013), which basically assigns a list of school options to each family according to the neighborhood of residence, but a policy that favors homeowners over renters in the access to public schools is also strictly enforced. In the city of Shanghai, a strict regulation commonly known as the "renter discrimination policy" is applied that strongly discourages Chinese families from settling for renting options (Feng and Lu 2013). In Chinese cities, the renter discrimination policy arose because the supply of places in local public schools exceeds demand, thus making it necessary to try to moderate access to the school enrolment process. The tenant discrimination policy ensures that children from families that own a house have enrolment priority by ranking them first on admissions lists, whereas children coming from tenant families are ranked after them (Zhang and Chen 2017). This "homeowner first and renter second" regulation, along with other government policies and initiatives, has fueled the Chinese housing market, causing the negative label of "naked marriage," or luohun, to be assigned to couples who get married without first having purchased a family home.

Mrs. Meng further explained that:

"It goes without saying that in such a competitive environment, where Chinese families are fighting for a place in a high-quality neighborhood school, this advantage that owners have over renters is extremely valuable and desirable. Consequently, middle-class urban families have a strong motivation to purchase a family home, although it is far from an easy goal to achieve given the skyrocketing prices in the Shanghai housing market."

${ }^{4}$ For further details on school policies in Shanghai, see also the recent article by Tan, C., "Neoliberalism as exception: The new high-quality school project in Shanghai", Discourse: Studies in the Cultural Politics of Education, 2019 
Such concerns about the pressure to buy a house to enable children to attend a good school were expressed by my male research participants, though with an emphasis on their roles as providers for their families. For instance, when I met Mr. Wang, he was living in a rented apartment in the suburbs of Shanghai. However, he was very excited because he had just moved into a bigger and better apartment of $60 \mathrm{~m}^{2}$, where he lived with his pregnant wife. His parents were about to move in as well to take care of their child. Every time we met during my fieldwork in Shanghai, he would express his concern about the housing market and its prices in this city. He often spoke about the responsibility men have for their family and his feeling of letting his family down in case of failure to achieve their housing goal. He explained:

"A family home is central. With an owned home you can potentially have everything: security, a good education for your children, 'face' in the eyes of family and friends, and even a Shanghai hukou. ${ }^{5}$ Without a house, everything is many times more difficult and you have no privileges."

Now that his child was due, his pressure to purchase a family home had become stronger and stronger: he repeatedly stated the importance of achieving this goal before their child is admitted to kindergarten.

"This is because, in China, there is path dependency in the quality of the schools a child attends: a good primary school leads to a good middle school, a good middle school leads to a good high school, and so on. Therefore, families like ours feel both the pressure and the urgency of purchasing a house as soon as possible."

All the men I interviewed during my fieldwork expressed concerns similar to those articulated by Mr. Wang. Moreover, Mr. Meng added:

"Of course we know how difficult it is to purchase a house in this city, and if we cannot afford it there is not much we can do but settle for other options. As for my family, we would move back to our hometown, Baoding in Hebei province, and purchase a house there where prices are lower."

However, some families were determined to stay in Shanghai even if they could not afford an apartment, hoping for the best. For instance, Mr. Tong explained:

"I see my family in Shanghai in the future because there are great opportunities for professional and personal growth here. I do not intend to go back to Jiangsu. Therefore, if our housing goals don't come true, I would still send my child to a Shanghai private school: we have enough money to pay the tuition fee of a good school and I would focus on money and career to bring my family a comfortable lifestyle and status."

Nevertheless, not every family can achieve their home owning goal, and many families remain "renters for life," especially migrant families. ${ }^{6}$ What are the most common

${ }^{5}$ The hukou system is a system of household registration in the PRC, which officially identifies a person as a resident of a specific urban or rural area. Holders of a local hukou usually enjoy more privileges than nonlocal hukou holders. 
options in this case? My respondents fell into two main categories: either opting for a private school or sending their child to a public school ${ }^{7}$ and then hoping for a hukou conversion (for those with non-local hukou) as well as relying on guanxi, i.e., networks, to obtain admission to a good school afterwards. For instance, Mrs. Deng said:

"There are two major obstacles for us to give our children a good education: house and hukou. My family wants to send our child to a public school, but if we don't buy a house, we most likely will only be admitted to an average school, if we are lucky. But if that is the case, we would accept it and work on our hukou conversion in the meantime, so that our child can go on with his or her studies in Shanghai. Another strategy is guanxi. Guanxi is key, and you never know when and if you can find useful guanxi: most families rely on networks to get into good schools and maybe we could do the same."

Other families, such as the Tong Family, were happy to send their child to a private school in case their home owning and hukou conversion dreams went awry: "Of course there are always private schools and, to be honest, their quality is improving, so the choice of a private school wouldn't be a disaster."

What emerges is that young families, especially migrant families and lower-income households, are subject to indirect discrimination due to their struggle to pursue the goal of purchasing a house in a good school neighborhood, adapting their housing strategies to the potential educational scenarios of their children. In fact, the tenant discrimination policy and the struggles to buy a house are closely connected, not only because owning a house is extremely beneficial to the enrolment of one's child in a local public school, but also because the renter discrimination policy creates a housing market with extremely high selling and reselling prices (Zhang and Chen 2017), which contributes negatively to the real-estate bubble that has hit Chinese cities over the last several years.

However, gaining advantages in terms of admission ranking in public schools is not the only school-related privilege granted to homeowners. In fact, as for migrant families specifically, owning a home in Shanghai contributes to gaining points within the local hukou application process: this process is composed of a total of 120 points, and after reaching this number one can try and apply for a Shanghai hukou. How are hukou and public schools connected? Possessing a Shanghai hukou is extremely important when aiming to give one's child a public education. Migrant families who do not possess a Shanghai hukou can temporarily apply for a Shanghai residence permit, which allows migrant children to attend a public school; however, there are limitations to elementary schools and middle schools (Ministry of Education 2017). Therefore, migrant parents should aim to convert their children's hukou into a Shanghai hukou in time for high school admission: only after reaching 120 points can a child be allowed to enroll in a public high school. Within the Shanghai hukou application process, an owned home not only enables its owner to accrue points towards a hukou conversion but also automatically grants migrants a Shanghai hukou seven years after the purchase of the property.

\footnotetext{
${ }^{6}$ The term "migrant" refers to individuals who have experienced rural-to-urban migration, intra-provincial or inter-provincial, and often start from a disadvantaged position, including a lower income and a non-local hukou.

${ }^{7}$ In China, public schools are usually preferred to private ones, which are generally believed to offer a lowerquality education and require the payment of tuition fees.
} 
Perceptions on the importance of house and hukou in obtaining cultural capital were well expressed by Mr. Mao during my fieldwork interviews:

"Purchasing a house in Shanghai is extremely important for our child's education also because of the hukou issue. I didn't consider changing my hukou until my child came along: I always thought that I could use money and career to improve my status. With kids it's different, and my wife and I would prefer to send our child to a public school. For families like us, who prefer public education, it is very important to obtain a hukou conversion. This is also for stability reasons: we wouldn't want to send our child to a public school in Shanghai until middle school and then have him change because of our hukou situation. Gaining stability through house and career can secure a local hukou, and we will do what we can to achieve this goal for our family."

However, in some situations, economic capital alone can represent a solution for securing a child a place in a good school, be it public or private. For public schools, there are cases where the neighborhood school policy is not rigorously applied and where ways exist to get around the regulation. There exists, in fact, a semi-official market for those children who are not eligible to attend a public school: families can sometimes be granted admission for their child by paying a high yearly fee, which in Shanghai is around 130,000 yuan. A report published in 2011 by the Institute for 21st Century Education states that despite the neighborhood school policy, a small number of exceptions still exist, due to those out-of-zone parents who pay a high extra admission fee to send their children to a key primary school. Therefore, although it is not always possible to access this informal market, Shanghai families know that economic capital can potentially be a way to secure a place for their children in their ideal school. As for expensive private local or international schools, it goes without saying that income can ensure admission without the need to satisfy other conditions.

An ideal solution to overcome such discrimination against tenants has not yet been found. What this situation seems to indicate is that if renters were allowed to enjoy the same privileges as homeowners, young families would see their credit constraints improved; furthermore, real-estate prices in neighborhoods with good quality schools would also be reduced in favor of a more balanced housing market.

Middle-class migrant families are struggling because of this policy, due to their realization of how important an owned home is for the future of their family and children. Hence, the data presented in this section contributes to showing how quality education is able to affect middle-class families' strategies in terms of economic capital, be it expressed in the form of homeownership goals or saving for special admission fees as well as for the more expensive private or international schools.

The next dimension to be analyzed pertains both social and symbolic capital, i.e., how quality education is able to affect neighborhood quality as well as perception of middle-class families' status and class membership.

\section{Class status and membership: the effects of "key" schools on neighborhood quality}

The most valuable private property of an urban Chinese household is their home. An owned home is the most desired asset for middle-class families, not only because of the 
home's intrinsic economic value, but also because of the symbolic value that owning a house entails: a house can increase the perceptions of one's social status and social class and allow for the creation and development of "high-quality" networks. However, the house and all the symbolic meaning it carries are not placed in a social vacuum but surrounded by other houses and other families that together constitute a neighborhood. Social class and social status are, in fact, socially determined and generated by the continuous and constructive interaction with the social context in which the family is living: families are, therefore, placed in a social and geographical context which is perceived as a projection of their ideas of class, status, and lifestyle. Consequently, families' social context of belonging, the basic unit of which is the neighborhood of residency, interactively affects a family's status and social class perceptions. In Shanghai, as an example, there are some neighborhoods as well as residential types (e.g., gated communities) that are perceived as being of a higher quality, and more prestigious than others, and therefore preferred by middle-class families who are striving to secure suzhi and a high social status. Taking a step further, the best neighborhoods are, in the eyes of Shanghai families, those which contain a high-quality key school. ${ }^{8}$

School and education can thus directly affect families' perception of social status and social class through the acquisition of cultural capital from the best schools in Shanghai. However, the renowned difference in school quality and the existence of key schools have also had important indirect effects on the perceived prestige of neighborhoods: in fact, when the quality of school education and other public services a family receives depends on the district the family resides in, this is naturally capitalized into the home value. Consequently, apartments located in good school neighborhoods are inevitably more expensive than average school neighborhoods. For the city of Shanghai, one key school per square kilometer raises average housing prices by approximately 19\%, and one Shanghai Experimental Model Senior High School per square kilometer increases housing prices by $21 \%$ (Zhang and Chen 2017). Being able to afford a house in a top neighborhood significantly affects families' share of symbolic capital.

However, this phenomenon of capitalization of school quality is not unique to China: it can be observed in Western societies as well, for example, in the UK. Parents in the UK are also willing to use any means in their power to secure their children a place at a top performing state school (Clapham et al. 2014): in order to move into a good school neighborhood, many families are paying the premium for a home near an esteemed school, not unlike the situation in China.

When looking at capitalization of school quality, it is important to notice how families' efforts to accumulate cultural, economic, social, and symbolic capital are embedded simultaneously in their housing strategy, as all of the types of capital are involved and contribute to the capitalization of school quality. Such an interrelation between different types of capital occurs because, as discussed previously in this article, the value

\footnotetext{
${ }^{8}$ The traditional education system in China is "exclusive," mainly due to the existence of the so-called "key" schools at different geographical levels. Key schools enjoy the best educational resources and admit students based on entrance examinations. The key school system was suspended during the Cultural Revolution, only to reappear in the late 1970s (Feng and Ming 2010). Owing to a lack of educational resources and teachers, selected "key" schools were prioritized in the assignment of teachers, equipment, and funds. Key schools are far fewer than regular schools and allow the best students to be admitted to the best secondary schools based on entrance scores. Although key schools no longer formally exist in today's China, they are still widely present in the perceptions of the very demanding Chinese parents.
} 
of capital is determined by its convertibility (Bourdieu 1984). In this specific case of the connection between children's education and housing strategies, the value of economic capital is that it can be converted into symbolic and cultural capital, which is key for middle-class families in securing high shares of other types of capital. Simultaneously, cultural capital allows for the acquisition of suzhi, a key element for middle-class families in securing social distinction.

Unfortunately, however, purchasing a house in a key school district and successfully enrolling one's child in the desired key school has become increasingly difficult. This is not only because of the increasing housing prices and competition in key neighborhoods, but also because of the increasing regulations enforced by the Shanghai local government which attempt to limit the turnover of apartments in order to ease the existing congestion in key school enrolment. For example, in April 2014, the government announced a new policy for the Jing'an district, one of Shanghai's central districts, with the aim of curbing the problem of excess demand for Shanghai's key school enrolment. According to this policy, only children from one family per apartment can enjoy the privilege of priority admission to enter a key primary school every five consecutive years (Zhang and Chen 2017). This means that if a family sells their apartment right after their child enters school, the new purchaser of the apartment must wait for another 5 years before the child can be granted the same privilege.

The definition of school attendance zones, which are published by schools in enrolment brochures, is also very specific: eligible areas are not drawn as a spatially closed boundary; instead, exact residential buildings and building complexes are named. This increases the congestion issue within key neighborhoods, which are subject to increasingly selective housing-school regulations. If, on the one hand, the strict rule has helped to prevent corruption in school enrolment, on the other, it has worsened social inequality in terms of intergenerational mobility, thereby posing a potential threat to the vitality of the city (Zhang and Chen 2017).

Another consequence of the school neighborhood policy, and a way in which school can affect perceptions of class and symbolic capital, is the phenomenon of residential segregation, caused by the tendency of higher income families to reside in expensive neighborhoods known for good schools. Residential enclaves are the units that constitute neighborhoods and districts, and they are in many respects enclosed societies. The core value of these residential communities is distinction, or the idea that residents of such communities are entitled to a sort of exclusiveness that distinguishes families living in these residential oases from the "outsiders." The biggest fear of gated community residents is that of "contamination" by the world outside the gates, which can potentially cause a loss of exclusiveness, a decrease in housing prices and the destruction of such a high-end and immaculate community (Pow 2007). This distinction is based on the idea that "outsiders" are low-quality individuals whose "contamination" would not only potentially disrupt the peace and order of the community, but most of all would negatively affect the image of the neighborhood. To promote an image of a highquality life, the entrances to these estates are often marked by magnificent gates, sometimes in the style of elaborate baroque facades. Because residents have been filtered through housing affordability, the estate is created as an "enclave" for those with similar socioeconomic status (Wu 2004). 
This generates a phenomenon of moral geographical segregation, where the morality of places is defined based on the exclusion of individuals of inferior quality living outside the community (Tomba 2014). The label "quality,", is the main factor that sets apart insiders and outsiders; however, another recurring label, mentioned many times during my interviews in Shanghai, is "civilized," or wenming: both of these labels define the Chinese middle class, differentiating it from the lower working class and poorer migrant workers. Mr. Meng stated:

"We want to live in gated communities in good neighborhoods, because they are a high-quality and civilized environment. Residents in these neighborhoods are also highquality and civilized, and I think it is the best environment to raise my family in."

His wife went on: "Good school neighborhoods are the best option for our family; it's like killing two birds with one stone: good schools bring good education and good neighborhoods." In Shanghai, the importance of maintaining a civilized modern living environment is underscored by an annual campaign whereby residential estates are awarded the official title of "Civilized Residential Quarter" by local district governments. However, this award is basically given by default, as nearly all gated communities in the city have this plaque displayed at the entrance gate.

With an increasing number of migrant workers coming into the city to search for job opportunities and earn money for their families, the necessity for middle-class families to secure strong boundaries between them and the lower classes is felt very strongly. Distinction is, in fact, the principal means to secure a strong middle-class belonging and middleclass reproduction of the family. This is especially true for middle-class migrant families, who have experienced hardship in the city and who come from a rural background.

Mr. Ye was very proud of his achievements so far, especially of his career and of what getting a good job has meant for his family. However, during our conversations, he could not stop stressing the fragility of his family's condition:

"I am very happy and very proud of what I have done so far. It is not easy for rural families who want a future in the city, you know, especially in a competitive city like Shanghai. We have come a long way, my girlfriend and I, and we want to keep moving forward for our kids and family. But our situation, although we are better off than other migrants, is really precarious, and I fear every day that I may lose everything and go back to where I started. That would be the biggest failure for me and my family. This is why I keep striving to get more and more: this way, if I lose a little, we can still be okay, right?"

His girlfriend added a different perspective:

"I also think that migrant families like ours have a stronger urge, compared to our urban counterparts, to keep up our families' 'face' and status. Most families are not happy when their children migrate: of course, they know about all the opportunities that there are in a city like Shanghai, but elder generations who were born and raised in the countryside still have preconceptions about life in the city. Our parents 
are always saying it's dirty, unsafe and that urban families are different. So I think migrant families need and want to prove their rural families wrong; we cannot conduct an average life here in Shanghai. We need to show them that we have reached a strong status for the family and that we are able to secure a bright future for our children. And this is all because of our decision to move here and leave the countryside behind."

What emerges from this data is that a common feeling among the middle-class migrant families I met was that belonging to a high-end, high-quality neighborhood identifies them with a high-quality and exclusive environment, benefiting the families' status and social class perception in the eyes of family and networks. This resonates with observations by several scholars that the affluent middle-class people in Shanghai buy into gated communities to try to establish themselves as refined residents living in civilized enclaves. Moreover, the new Chinese middle class demands housing that meets the standards of their new acquired sensibilities, i.e., gated communities combined with excellent transport facilities and key schools, in order to enjoy the privileges that owe to what Chen and Goodman (2013) call "housing status-groups" membership: according to the authors, private housing in high-status gated communities has at all effects created a new privileged social group, an affirmation which fully resonates with the findings of this dissertation. Belonging to an exclusive community implies belonging to a high social class in the eyes of family and networks; therefore, exclusive, quality school neighborhoods represent a strong means for securing symbolic capital as well as high-quality social capital.

\section{The effects of quality education on cultural capital}

In September 2018, Mrs. Shi contacted me to discuss a story that had gone viral on WeChat and Weibo in a matter of days. An elementary school in Suzhou had been divided into two areas by a fence: the rich children on one side and the migrant children on the other. Mrs. Shi explained the situation, which profoundly shocked her:

"It's unbelievable, the campus has been divided in two: on one side are 800 migrant students and on the other 400 students from local rich families who own expensive apartments near the school. The complaint obviously came from the rich parents who don't want their children sharing exclusive education resources with migrant students with no local hukou. I read that the migrant students are all between 8 and 12 years old and were previously enrolled in a migrant school, Lixin. After the school closed, the 800 students were transferred to the nearest school that was able to receive such a high number of students: the exclusive experimental elementary school of Qixi. At the end of August, the rich parents who had spent nearly 28,000 yuan/sqm to purchase an apartment in that neighborhood started to feel threatened because their children's academic success was now in danger due to the presence of unqualified students. Not only this, these parents also said the situation was unfair: after all, they had invested a lot in order to grant their children such an exclusive education. I believe it is a question of exclusiveness: middle-class families invest in order to be above their peers and do not want to share their exclusive territory with 
the working class or the migrants. Look at these parents: what they fear is contamination and loss of exclusiveness."

The exclusiveness that high-end neighborhood communities bring are attracting the ambitions of Shanghai's middle- and upper-class families, who view high-quality and exclusive districts as a means of securing middle-class status and being associated with a high-quality lifestyle.

In the previous section, the core of the analysis was the indirect effect that key schools have on neighborhood quality and exclusiveness: therefore, schools can indirectly affect a neighborhood's and a community's symbolic and social capital, thereby increasing a family's status and social class. However, high-quality schools can also affect status and social class through the enhancement of families' shares of cultural capital, which can be strengthened by receiving education in Shanghai's best schools.

Middle-class families can afford expensive housing in high-end neighborhoods, and they are also the social class that shares a strong inclination towards human capital investment. Such an inclination makes wealthier families willing to pay for a high-quality education and all that is required in order to achieve it.

As well as being the primary source of suzhi, cultural capital can also be converted into economic, symbolic, and social capital. Potentially, quality education can lead to a greater career, greater earning, high-quality social networks, and a middle-class reproduction of the household. Therefore, middle-class families in China are willing to spend a small fortune on their children's cultural capital: in China, this "education fever" is a phenomenon widely present among members of the middle class, reflecting one of the renowned characteristics of this social class group: pragmatism. As Mrs. Liang stated: "I'm not really interested in luxury goods. I would rather spend my money on my child's education because it has a higher return on investment than any other luxury good." Education and cultural capital, in fact, are one of the strongest means of ensuring distinction to a family, as Mrs. Mao explained:

"If I can give my child the best education possible and he can attend Shanghai's best schools, he will stand out among his peers and have the best opportunities when he grows up. Today, the idea of comparing luxury goods to show off social status is outdated; Chinese parents prefer comparing their children's education level".

What emerges is that education is paramount for middle-class families; however, education is only one aspect of cultural capital, which consists of a wide set of a person's social assets (education, intellect, style of speech and dress, etc.), which promote social mobility in a stratified society (Bourdieu 1984) and confer social status and power. In this final section of the article, I intend to show how quality education can affect other dimensions of cultural capital.

As stated by Mr. Meng, only after he moved to the city did he deeply understand the "practical" value of education, which creates well-rounded and strongly-opinioned individuals:

${ }^{9}$ See the interview with Ma Li on The Sixth Tone for the full story at http://www.sixthtone.com/news/1002 855/why-chinas-migrants-cant-just-leave-poverty-behind 
"I think that education is the most important thing, even more important than money. You know, there are many rich people in China who have a lot of money but little education, and I do not want to become one of them. Education makes us better people and opens up a lot of opportunities: without education, I would still be in my village, I wouldn't have got this job as a software engineer in a good international company, and I wouldn't understand the world the way I do today. Without education, I would still be the same as many years ago. Education brings development, and I wish to share all the things I've learned with my kids."

The possession of cultural capital is also important because it affects how the middle class can distinguish themselves from the working class and from poorer migrant workers.

My research participants often made comments about what Bourdieu would refer to as the "habitus" of people from lower social classes. These comments elucidated what they saw to be the important elements of distinction between the upper and lower classes. As one example, when I asked him to elaborate on his statement about the importance of language and style, Mr. Meng told me:

"I know that we shouldn't be judging the quality of people based on assumptions made by looking at their clothes, or by noticing their accent when they speak. But often we do not have the opportunity to deepen our acquaintance with every person we meet, and first impressions are taken very seriously here in Shanghai."

He went on to explain, supported by his wife, that poorer migrant workers are characterized by a strong Mandarin accent and by "unstylish" clothing, features which single them out immediately as belonging to a lower social class. Mrs. Wang also explained that poorer migrant children prefer to socialize within their community, since within their community of belonging kids all share the same socioeconomic background, whereas they struggle to conform to urban communities mostly because of language and esthetic preconceptions. Although migrant workers look increasingly like urban workers, middle-class families still feel that these language and clothing distinctions are extremely important in setting them apart from the lower classes, and so they strive hard to conform to the government-promoted standards of Mandarin skills and lifestyle.

Closely connected to the idea of suzhi is that of wenming, or the ideal of being a civilized individual. These two concepts are often used by the Chinese government in its propaganda, in an attempt to promote ideas of social distinction. This propaganda is also used by the government in residential planning: as discussed in the previous section, gated communities and residential enclaves are used for the purpose of social clustering and engineering: the "Civilized Residential Quarter" award serves just the purpose of example setting. Therefore, being "civilized" sets apart the middle class from the working class, who are considered rude in their manners. Suzhi and wenming are extremely important for middle-class families: going back to Bourdieu, a high economic capital alone does not make an individual a member of the middle class. While reaching a middle-class status is seen as an ideal goal, terms such as "new rich" or "second generation new rich" have increasingly been used as derogatory terms to indicate individuals who have accumulated wealth but are still low quality and largely uncivilized. 
My middle-class respondents all tended to talk about the "new rich,", as though they incorporated all of the moral and social problems of China's rapid and unequal economic and social development. For instance, Mrs. Tong stated:

"The impression of the new rich category is very similar to that of poorer migrant workers, minus the stigma of poverty. The new rich, as well as their children, are seen as rude, uncivilized and even capable of vandalistic acts, and therefore, together with the migrant workers, they are not perceived as welcome inside exclusive gated communities."

During my fieldwork, I spent time with a family (the Shi Family) where the husband was considered a "new rich." He lacked cultural capital, but he had good shares of economic capital, which he frequently bragged about both directly and indirectly: in fact, he mostly spent his money on extravagant and branded purchases, which he viewed as a material projection of his personal success. However, he and his original family felt extremely insecure about their status, which was based on economic capital alone, and he often behaved rudely towards his wife and her family, who were educated middle-class people. On the other hand, her family often complained about the husband's lack of cultural capital, even their teenage son, who refers to his father as a person with no culture, therefore, will not let him attend his parent-teacher meetings for fear of losing face. This specific situation, which is not uncommon in China, shows that the possession of economic capital alone does not secure middle-class status without cultural capital.

A degree and a good job allow middle-class individuals to increase all four types of capital, but what really sets them apart from the lower classes is the acquisition of cultural capital, from which the other three types derive. Mr. Wang, for example, obtained a degree in engineering at the University of Anhui and then moved to Shanghai to work for a very prestigious international high-tech company. Because of his degree and his job, he increased his shares of cultural and economic capital, from which derived an increase in symbolic and social capital. During his accounts of family meetings in his home village, in particular during the Chinese New Year holidays, he shared this thought: "For higher status migrants, going back home is desirable only for a short period of time, and this is mostly due to the educational gap between us and the left-behind relatives." In other interviews, most middle-class migrants used the word "rude," when describing their relatives, as well as "of lower quality,". Therefore, they often engaged in leisure activities together, such as cards or majiang, in an attempt to create an environment of similar socio-cultural conditions.

Clearly, middle-class families are willing to invest in housing as well as to adapt their family strategies with the final goal of guaranteeing the best education possible for their children. Quality education, in fact, is able to affect an individual's share of cultural capital, which has been shown to be the type of capital with the highest convertibility rate. Cultural capital, indeed, leads to a higher suzhi, which lies at the basis of distinction and social standing and which increases the odds for a middle-class reproduction of the household. 


\section{Concluding discussion}

The present article has attempted to provide an answer to the research question: "What are the effects of quality education on middle-class families' ideas of class and status?" by considering three key dimensions of analysis, along with Bourdieu's types of capital: economic capital, where I compare renters and homeowners as pertains the school enrolment process; social and symbolic capital, where I highlight the correlation between quality education and neighborhood quality, as well as status and class membership; and ultimately cultural capital, where I present the effects and implications of quality education on wider dimensions of cultural capital for the new Chinese middle class.

Indeed, the education of their children was considered paramount by my respondents and the pursuit of quality education has affected their family strategies in several respects, which I have classified according to Bourdieu's four types of capital.

As for the effects of quality education on economic capital, the option of a good school for one's child strongly drove the families I visited to want to purchase rather than rent a family home. Moreover, because housing strategies gravitate around school options, a two-way dependency was created between school and education, on the one hand, and class, status, and housing on the other. This correlation also implies that the four types of capital that make up the middle class (economic, cultural, social, and symbolic) are closely connected within families' housing and education strategies.

The middle-class families I knew were willing to sacrifice their economic capital in order to secure symbolic and social capital: living in a high-end neighborhood benefitted perceptions of status and social class. It also benefitted opportunities for accruing social capital because living in high-end communities implied sharing a living environment with high-class networks. Symbolic and social capital could, in turn, help families obtain the best education possible for their children, thereby ensuring further middleclass status and belonging. Ultimately, quality education is able to increase middle-class families' shares of cultural capital, which allows for a consequential increase of their degree of "qualitative value" as well as "civilization." The strengthening of their cultural capital, moreover, leads to the establishment of stronger symbolic boundaries between their own social class group and other lower as well as higher income groups, such as the new rich, who have increased their economic capital at the expense of cultural capital and are generally viewed negatively by the Chinese population.

The heterogeneity of the Chinese middle class (Goodman 2014; Miao 2016), as well as the precariousness of middle-class membership, is the cause for the need to create strong symbolic boundaries to demarcate both intra-class and inter-class differences (Bourdieu 1984). Furthermore, what allows middle-class individuals to secure distinction within such a precarious class group is the possibility of enjoying inclusions and exclusions that can limit or promote social mobility (Tomba 2005). As my analysis shows, quality education is generally considered by the Chinese middle class as one of the keys for social mobility, as it is the type of capital which enjoys the highest convertibility.

Another key element in the social reproduction process is homeownership and housing, not only due to the clear connection between house, neighborhood, and school quality, but also due to other privileges which an owned home is able to grant middleclass families, which are not hereby discussed. As for education, all middle-class families aim at securing a house at least before their child starts school and, even better, in 
a good school neighborhood. Housing and neighborhood are, therefore, key means to achieve middle-class families' cultural capital goals.

A theoretical model that effectively categorizes class membership while considering the relational aspect of class is the one hypothesized by Bourdieu, which has been used as a theoretical framework for this article.

Different relevant studies on class and class identity have been based on various theoretical approaches, the most common being Weber's theoretical framework that explains social strata (e.g., Anagnost 2008; Woronow 2011) and Marx's definitions of class as well as class conflict (e.g., Pun and Smith 2007; Pun and Lu 2010). However, for this article, I have personally selected and used Bourdieu's theoretical approach. Whereas most relevant studies tend to apply a Weberian approach to explain social class in China (e.g., Tomba 2004; Anagnost 2008; Woronow 2011; Guo 2012), I believe that Bourdieu's interpretation of the four species of capital is a framework that better allows us to define and identify middle-class membership. In fact, the Bourdieusian approach clearly distinguishes between four types of capital that are necessary to draw the symbolic boundaries that discern different types of social groups, e.g., the new rich (who merely possess economic capital) and the middle class (which mainly possesses cultural capital).

Existing studies have applied Bourdieu's theoretical tools to class analysis. Among relevant studies, Biao (2003) analyzed the role of capital convertibility in class consolidation processes centered on the acquisition of cultural capital through foreign education, and Hanser (2006) adopted the Bourdieusian approach to explore service interactions and the pursuit of distinction by Chinese working-class clerks. However, the Bourdieusian model has so far limited applications in studies of the Chinese middle class or as a means to pursue discussions on status and class-formation dynamics in China.

Although, as discussed in the introductory section of this article, many relevant studies have been conducted on the Chinese education system and on the "education fever" phenomenon pervading contemporary China, few studies so far have explored the class-related reasons behind the paramount importance given to quality education. The result of this is a partial understanding of a phenomenon that is extremely relevant for contemporary China and that is greatly complex and multifaceted. In this article, I attempt to address this issue, and provide a wider perspective on the significance of quality education for the Chinese middle class. Hence, I hereby contribute to the existing literature on education, housing, and middle class by exploring the interconnection between quality education and ideas of class and status, as well as the different dimensions and implications of cultural capital for the new Chinese middle class and its ideas of social standing. Sure enough, the Chinese middle class does not only pursue quality education for reasons of career and wealth, but also for deeper and more complex class-related implications, as are the effects on families' cultural, economic, social, and symbolic capital. Quality education is to be considered, therefore, one of the key elements of classlegitimation and social mobility for the new Chinese middle class.

Acknowledgements

I would like to thank Dr. Rachel Murphy for her invaluable insights and advice, and the Torino World Affairs Institute for their constant support and encouragement. 
Author's information

Arianna Ponzini is a Junior Research Fellow at the Torino World Affairs Institute and received her Ph.D. in Oriental Studies (with a focus on contemporary Chinese sociology) from the University of Oxford.

Funding

None.

\section{Availability of data and materials}

The data used in this article is of qualitative nature and much of it is available in this article.

\section{Ethics approval and consent to participate}

My research project involves human participants, and therefore, I have submitted the CUREC A1 form to receive ethical approval for my work from the University of Oxford. My work has been assessed as of no risk in terms of ethical code infringement. No children have been interviewed and the research questions are not of a sensitive nature. During the interview process, I have provided my respondents with an information sheet and have requested oral consent from them. Therefore, I believe that no further ethical review is necessary.

\section{Consent for publication}

The subjects in this study are referred to using pseudonyms, therefore protecting the participants' privacy. Furthermore, all of the participants have expressed their consent and even encouraged publication of this research project.

\section{Competing interests}

The authors declare that they have no competing interests.

Received: 19 July 2019 Accepted: 20 December 2019

Published online: 23 January 2020

\section{References}

Anagnost, Ann. 2004. The corporeal politics of quality. Public Culture 16 (2).

Bourdieu, Pierre. 1984. Distinction (cursive). London, Routledge.

Chen, Minghu and Goodman, David 2013. Middle Class China: Identity and Behaviour. Edward Elgar.

Clapham, David, Mackle, Peter and Orford, Scott 2014. The housing pathways of young people in the UK. Environment and Planning A: Economy and Space 46 (8).

Feng, Hao and Lu, Ming. 2013. School quality and housing prices (Shanghai). Journal of Housing Economics, 2013, vol. 22, issue 4 , 291-307.

Fong, Vanessa. 2006. Only Hope: Coming of age under China's One-Child Policy. CA, Stanford University Press.

Goodburn, Charlotte. 2009. Learning from migrant education: a case study of the schooling of rural migrant children in Beijing. International Journal of Educational Development 29 (5).

Gu, J., et al. 2018. Higher education in China. Springer.

Hanser, Amy. 2006. Sales floor trajectories: distinction and service in postsocialist China. Ethnography 7 (4): $461-491$.

Hanser, Amy. 2008. Service Encounters: Class, gender, and the market for social distinction in urban China. CA, Stanford University Press.

Jacka, Tamara. 2009. Cultivating citizens: Suzhi (quality) discourse in the PRC. Positions: East Asia Cultures Critique 17 (3): $523-535$. Kipnis, Andrew. 2006. Suzhi: a keyword approach. The China Quarterly 186:295-313.

Price, R.F. 2017. Education in communist China. Routledge.

Qian, Haiyan and Walker, Allan 2015. The education of migrant children in Shanghai: the battle for equity. International Journal of Educational Development 44: 74-81.

Tan, C. 2015. Education policy borrowing and cultural scripts for teaching in China. Comparative Education, 51(2):196-21.

Tan, C. 2019. PISA and the education reform in Shanghai. Critical Studies in Education.

Tomba, Luigi. 2004. Creating an urban middle class: social engineering in Beijing. The China Journal: 51:1-26.

Tomba, Luigi. 2009. Of quality, harmony and community: civilization and the middle class in urban China. Positions Asia Critique 17 (3). Tomba, Luigi. 2010. Gating urban spaces in China: inclusion, exclusion and government. Gated Communities, London, Routledge, 2010.

Tomba, Luigi. 2014. The Government Next Door: Neighborhood politics in urban China. New York: NY, Cornell University Press. Wu, Weiping. 2004. Sources of migrant housing disadvantage in urban China. Sage Journals 36 (7).

Xiang, Biao, and Shen, Wei. 2009. International Student migration and social stratification in China. International Journal of Educational Development 29(5):513-522.

Zavoretti, Roberta. 2016. Rural Origins, City lives. Seattle, University of Washington Press.

Zhang, Muyang, and Jie, Chen. 2017. Are Chinese paying too much or too little for school quality? Asian Development Bank Institute: 724

\section{Publisher's Note}

Springer Nature remains neutral with regard to jurisdictional claims in published maps and institutional affiliations. 